\title{
Tradisi Ritual Masyarakat Desa Rawabogo Ciwidey Sebagai Daya Tarik Desa Wisata
}

\author{
Oda I.B. Hariyanto ${ }^{1}$ \& Dame Afrina Sihombing ${ }^{2}$ \\ ${ }^{1}$ Universitas Internasional Batam, oda@uib.ac.id \\ ${ }^{21}$ Universitas Internasional Batam, dame@uib.ac.id
}

\begin{abstract}
ABSTRAK
Mengembangkan suatu desa menjadi desa wisata merupakan salah satu strategi pemerintah dalam mempercepat membangunan desa tertinggal. Melalui pendekatan pengembangan wisata alternative, untuk merealisasikan pembangunan pariwisata dengan mengemas suatu pedesaan menjadi desa wisata. Pada umumnya desa telah memiliki potensi dasar yang belum tersentuh dan dikembangkan, seperti kekayaan alam, keunikan budaya dan kuliner tradisional. Potensi dasar yang telah dimiliki oleh masingmasing desa merupakan modal utama sebagai daya tarik wisata desa, dapat dikembangkan sebagai diversifikasi produk wisata, dan pasar wisata. Untuk meningkatkan target kunjungan wistawan 2020, adalah 20 juta wisatawan mancanegara. Kondisi kehidupan perkotaan yang semakin padat kesibukan yang tinggi dan kemacetan semakin meningkat. Kini destinasi desa wisata semakin banyak diminati oleh wisatawan mancanegara, wisatawan Nusantara, maupun wisatawan lokal. Membangun suatu desa wisata sekaligus untuk mengembangkan identitas atau ciri khas daerah dan meningkatkan taraf hidup masyarakat serta menciptakan lapangan pekerjaan baru sehingga mengurangi pengangguran dan kemiskinan. Metode penelitian yang digunakan adalah deskriptif kualitatif menggunakan pendekatan multidisiplin, dengan alasan bahwa penelitian ini merupakan fenomena sosial-budaya dengan latar yang sesungguhnya atau alami, dan kekinian. Data yang dihasilkan berupa data deskriptif. Kebaharuan dari penelitian ini adalah munculnya sebuah desa menjadi daya tarik wisata baru atau alternative yang banyak diminati oleh masyarakat kota.
\end{abstract}

Kata Kunci: Tradisi, ritual potensi desa sebagai desa wisata

\begin{abstract}
Developing a village into a tourist village is one of the government's strategies to accelerate the development of disadvantaged villages. Through an alternative tourism development approach, to realize tourism development by packaging a village into a tourist village. In general, villages have basic potential that has not been touched and developed, such as natural wealth, cultural uniqueness and traditional culinary. The basic potential that has been owned by each village is the main capital as a village tourist attraction, can be developed as a diversification of tourism products, and tourist markets. To increase the visiting target of 2020 tourists, there are 20 million foreign tourists. Urban living conditions that are increasingly densely packed and congestion are increasing. Now the tourist village destinations are increasingly in demand by foreign tourists, Nusantara tourists, and local tourists. Build a tourism village as well as develop regional identities or characteristics and improve people's living standards and create new jobs so as to reduce unemployment and poverty. The research method used is descriptive qualitative using a multidisciplinary approach, arguing that this research is a socio-cultural phenomenon with a real or natural setting, and current. The resulting data is descriptive data. The renewal of this research is the emergence of a village as a new tourist attraction or alternative that is much in demand by the city community.
\end{abstract}

Keywords: Tradition, ritual village potential as a tourist village

Diterima: 14 Desember 2018, Direvisi: 27 Januari 2018, Diterbitkan: 15 Februari 2019

\section{PENDAHULUAN}

Keberadaan suatu bangsa tidaklah terlepas dari masa lalu, karena keberadaan masa kini terbentuk oleh peradaban masa lalu. Peradaban manusia masa sekarang akan membentuk peradaban masyarakat di masa yang akan datang, maka masa lalu merupakan sebuah pelajaran yang harus dipelajari. Masa sekarang merupakan hal yang harus dijalani sebaik mungkin, dan masa depan merupakan penerapan hasil pembelajaran dari 
masa lalu dan masa sekarang. Begitu banyak hal yang dapat dipelajari dari masa lalu salah satunya tentang tradisi dan ritual suatu masyarakat (Sudjana., Hartati, 2011). Tradisi dan ritual sebagai bukti sejarah atau artefak yang di diwariskan dari generasi ke generasi. Pada kenyataannya sebagian masyarakat dan generasi muda hampir tidak memahami tradisi dan ritual sebagai warisan budaya yang harus dipertahankan dan dilestarikan. Tradisi merupakan warisan kebudayaan dari masa lalu yang di wariskan secara turun menurun. Tradisi berasal dari nenek moyang yang biasanya memiliki ciri khas masingmasing sesuai dengan kebudayaan mereka. Sedangkan adat istiadat merupakan bagian dari tradisi yang berisikan himpunan kaidah-kaidah sosial yang memandu manusia untuk berperilaku baik dan benar. Masyarakat Desa Rawabogo Ciwidey, Kabupaten Bandung merupakan salah satu desa dari sepuluh desa yang dipilih menjadi desa wisata. Tujuan pemerintah mengembangkan desa-desa menjadi desa wisata, pertama untuk membangun desa tertinggal melalui koperasi dan usaha kecil menengah (UKM) kedua untuk mengembangkan desa yang memiliki potensi pariwisata. Ketiga Melestarikan adat istiadat dan ritual sebagai atraksi wisata, keempat meningkatkan taraf hidup masyarakat desa.

Penelitian Indah dkk., (2015), pendekatan pengembangan wisata alternatif untuk dapat merealisasikan pembangunan pariwisata adalah dengan mengemas suatu pedesaan menjadi desa wisata. Membangun suatu desa wisata sekaligus untuk mengembangkan identitas atau ciri khas daerah.

\section{KAJIAN LITERATUR}

\section{Tradisi dan Adat-Istiadat}

Tradisi memiliki pengertian yang luas dan umum sebagai warisan kebudayaan dari masa lalu yang di wariskan secara turun menurun. Tradisi berasal dari nenek moyang yang biasanya memiliki ciri khas masing-masing sesuai dengan kebudayaan mereka, kearifan lokal merupakan bagian dari tradisi. Penelitan Hariyanto, (2017) Local wisdom is cultural heritage in the past that is preserved from generation to next generation; hereditarily it becomes lifeline by the local society. Local wisdom is formed as the outstanding of society culture which contains values, norms, ethics, trust, customs, and customary law, in order human to behave wisely to the Creator, others, and the universe. Setiap etnis atau daerah memiliki tradisi yang berbeda-beda dengan keunikan sebagai ciri khas dari masing-masing etnis. Indonesia merupakan negara kepulauan yang memiliki banyak suku, dan kepercayaan. Dari ujung Barat sampai ujung Timur Indonesia memiliki beragam tradisi unik yang berbeda - beda pada setiap daerah. Ada tradisi khusus dari mulai lahir hingga meninggal (cycle life) seperti tradisi upacara ngaben di Bali, tradisi yang ekstrim dilakukan oleh suku Dani. Tradisi wanita suku Mentawai dalam mempercantik diri, meruncingkan gigi dan mentato tubuh, dan masih banyak yang unik lainnya seperti ritual mensyukuri panen. Kehidupan dan keseharian suku Badui di Banten yang sangat unik dan menarik perhatian untuk dipelajari (live in) bersama mereka dan lain-lain, menjadi daya tarik dan atraksi wisata atau obyek wisata. Sedangkan adat istiadat lebih spesifik, berhubungan dengan sikap dan kelakuan atau aktivitas seseorang yang diikuti oleh orang lain dalam suatu proses waktu yang cukup lama. Dilakukan oleh suatu masyarakat secara berulang dalam jangka waktu tertentu, sehingga menjadi ciri khas dari suatu suku atau masyarakat dari suatu daerah. Adat dapat dipahami sebagai tradisi lokal atau local castom yang mengatur, kata "adat" lazim dipakai tanpa membedakan mana yang mempunyai sanksi sosial di masyarakat.

Tradisi dan adat istiadat termasuk ritual merupakan modal utama yang telah dimiliki secara turun-temurun oleh masyarakat desa. Oleh sebab itu setiap desa memiliki potensi untuk dikembangkan menjadi desa wisata. Dalam suatu tradisi selalu ada hubungannya dengan upacara tradisional, upacara tradisional atau ritual merupakan bagian yang integral dari kebudayaan masyarakat pendukungnya (Khoiri, 2009), dan selalu menjadi daya tarik bagi wisatawan. Dalam Undang-undangan Kepariwisataan, (2009), daya tarik wisata adalah segala sesuatu yang memiliki keunikan, keindahan, dan nilai yang berupa keanekaragaman kekayaan alam, budaya, dan hasil buatan manusia yang menjadi sasaran atau tujuan kunjungan wisatawan.

\section{Ritual}

Ritual merupakan serangkaian kegiatan yang berhubungan dengan kepercayaan dan adat-istidat dari suatu masyarakat atau suku. Dalam upacara ritual banyak hal kegiatan yang dilakukan, dan dikaitkan dengan maksud dan tujuan berupa harapan dan permohoanan kepada Yang Kuasa, dan juga kepada khalayak atau masyrakat. Ritual merupakan tata cara dalam upacara atau suatu 
perbuatan keramat yang dilakukan oleh sekelompok umat berdasarkan kepercayaannya. Ditandai dengan adanya berbagai macam unsurunsur dan komponen, waktu, tempat-tempat dimana upacara dilakukan, alat-alat dalam upacara, serta orang-orang yang menjalankan upacara (Koentjaraningrat, 1980)

Pada upacara riutal biasanya disajikan beberapa jenis makanan sebagai persembahan, dalam bahasa Jawa disebut sajen yang berarti menyajikan sesaji dalam bentuk makanan. Sekarang, persembahan Makanan tidak sebagai sajen tetapi disajikan kepada teman-teman, atau sebagai persembahan untuk memenuhi ketentuan tradisi (Hariyanto, 2017).

\section{Daya Tarik Desa Wisata}

Pembangunan pariwisata kini difokuskan untuk membangun desa wisata. Kementrian Pariwisata (KEMENPAR) bekerja sama lintas sektoral, dengan Kementrian Desa, Pembangunan Daerah Tertinggal dan Trasmigrasi, Kementerian Koperasi dan Usaha Kecil, dan Menengah. Untuk mewujudkan 20.000 rumah singgah atau home stay, karena diyakini bahwa setiap desa memiliki potensi lokal yang dapat di kembangkan melalui pengembangan produk unggulan desa, seperti keunggulan alam, sosial ekonomi dan budaya desa tersebut. Desa wisata adalah suatu bentuk integrasi antara atraksi, akomodasi dan fasilitas pendukung yang disajikan dalam suatu struktur kehidupan masyarakat yang menyatu dengan tata cara dan tradisi yang berlaku di desa tersebut. Dalam suatu wilayah pedesaan yang memiliki potensi keunikan dan daya tarik wisata yang khas, baik berupa karakter fisik lingkungan alam pedesaan maupun kehidupan sosial budaya kemasyarakatan

Keberhasilan suatu desa dalam membangun desanya menjadi desa wisata, melalui pendekatan sebuah konsep yang menekankan kepada masyarakat untuk mampu mengelola dan mengembangkan objek wisata oleh masyarakat lokal tersebut, community based tourism (CBT). Penelitian A'inun, dkk., (2015) Pengembangan desa wisata dapat memberikan dampak positif bagi masyarakat desa itu sendiri, diantaranya adalah akan adanya lahan pekerjaan baru bagi masyarakat sehingga dapat menurunkan angka pengangguran di desa tersebut, selain itu desa wisata yang mengusung konsep ekowisata akan membuat suatu desa dapat mempertahankan kelestarian alam dan budaya desanya.

\section{METODOLOGI}

Metoda penelitian yang digunakan adalah metode penelitian kualitatif dengan alasan penelitian yang dilakukan merupakan fenomena sosial-budaya dengan latar yang sesungguhnya atau alami, dan menghasilkan data deskriptif (Ratna, 2007). Pendekatan yang dilakukan menggunakan multidisiplin. Boeije (2010) To analyze social cultural problems needed to involve some perspective of another sciences, like method, theory and other characteristic that could be used to analyze social-culture phenomenon. Qualitative research did not emphasize on number, data obtained was in form of words or pictures. Sedangkan Obyek penelitiannya merupakan studi kasus adalah Tradisi masyarakat Desa Rawa Bogo Ciwidey. Teknik pengumpulan data melalui observasi, analisis dokumen secara off line maupun online, dan wawancara mendalam (indepth-interview), untuk mendapatkan narasumber kunci (key informan) yang tepat pemilihan informan dilakukan dengan cara teknik bola salju (snowball sampling), sehingga narasumber kunci tersebut dapat memberikan informasi dan data yang akurat dan tepat. Tahapan analisis data dilakukan dengan cara reduksi data, tampilan data, analisis teknik triangulasi, dan verifikasi data, terkhir kesimpulan (Bachri, 2010)

\section{HASIL DAN PEMBAHASAN \\ Desa Rawabogo Ciwidey}

Desa Rawabogo terletak di Kecamatan Ciwidey, Kabupaten Bandung, provinsi Jawa Barat. Luas wilayah desa Rawabogo 759.800 Ha sebagian besar wilayah desa Rawabogo merupakan daerah persawahan dan perkebunan. Jumlah penduduk mencapai 7.653 jiwa, mayoritas penduduk adalah Suku Sunda. Desa Rawabogo merupakan daerah persawahan dan perkebunan, mayoritas mata pencaharian penduduk Desa Rawabogo adalah petani, buruh tani, dan peternak. Desa Rawabogo terpilih menjadi salah satu desa wisata dari 10 desa wisata di Kabupaten Bandung karena memiliki potensi yang sangat besar antara lain wisata alam, wisata spiritual, wisata budaya dan wisata kuliner.

\section{Tradisi dan Ritual Masyarakat Desa Rawabogo Ciwidey}


Setiap tahun masyarakat Rawabogo Ciwidey melaksanakan kegiatan tradisi yang dinamakan sawelas sasih yang artinya dalam penanggalan kalender Sunda jatuh di setiap tanggal 11 suklapaksa, bulan Badra atau tahun Baru Sunda. Kata Sawelas Saasih artinya dalam bahasa Indonesia artinya bulan sebelas. Dalam penyebutan sehari-hari mengalami suatu perubahan penghilangan suku kata sebagian atau beberapa suku kata untuk mempermudah tuturan atau ucapan. Gejala bahasa tersebut dinamakan elipsis atau majas yang menghilangkan sebagian suku kata atau kalimatnya. Majas sering digunakan dalam karya sastra berbentuk puisi. Majas adalah bahasa kiasan yang digunakan pengarang di dalam karya sastra dengan kesan tertentu untuk mewakili gagasan yang ingin disampaikan (Munir, 2013) Demikian halnya dari kata Sawelas Saasih untuk memudahkan ucapan menjadi sawelas asih yang memberikan makna baru yaitu memiliki sifat mengasihi atau saling mengasihi. Dalam kegiatan tradisi dan ritual "sawelas asih" di tampilkan musik, nyanyian dan tarian, sebagai rasa syukur kepada Yang Maha Pencipta yang telah memberikan keindahan alam dan kemakmuran kepada masyarakat di Rawabogo Ciwidey. Desa wisata Rawabogo memiliki Keindahan alam dengan hamparan hijau persawahan dan perkebunan yang terbentang bagaikan permadani alam. Tradisi ritual "sawelas asih"diadakan di Gunung "Nagara Padang yang memiliki hamparan batuan yang merupakan peninggalan situs megalitikum, hal tersebut menjadi daya tarik wista alam sekaligus melestarikan tradisi sunda dalam mengungkapkan rasa indah dan mengsyukuri, merupakan dasar

hubungan antar Maha Pencipta dan yang diciptakan dengan tujuan termulia dari keberadaan manusia yaitu cinta kasih. Di Indonesia memiliki banyak peningggalan situs megalitikum seperti di Kerinci, Pasemah dan Di Batu Sangkar tanah datar Sumatera Barat, Nias dan Toba. Hal tersebut menjadi destinasi para peneliti arkeolog dari Barat maupun dari Indonesia.

\section{Daya Tarik Desa Rawabogo Ciwidey Sebagai Desa Wisata}

Hamparan hijau dengan pemandangan yang indah, masyarakat yang ramah penuh senyum menggambarkan ciri khas masyarakat Desa di Rawabogo dan pada umumnya masyarakat Sunda di Jawa-Barat. Desa Rawabogo merupakan pintu masuk ke situs megalitikum Gunung Padang yang terletak di perbatasan Kecamatan Ciwidey dan Cililin, Kabupaten Bandung Barat. Masyarakt memberi nama pada batu tersebut batu lawang saketen, batu masjid, batu keraton, batu lorong, batu kidang kencana, batu leuit salawe jajar, batu kacapi, dan batu gedag. Selain kondisi alam dan situs megalitikum yang memikat sebagai destinasi alam. Kekayaan budaya yang dimiliki seperti kemahiran bermain egrang yang terbuat dari bamboo sebagai permainan tradisional. Kerukunan, dan azas kegotong royongan yang diambil dari filosofi Sunda Sabilulungan, silih asah, asih, asuh wawangi. Di Gunung Padang desa Rawabogo juga terdapat Makam Keramat Kerajaan Galuh hal tersebut memungkinkan juga menjadi destinasi wisata spiritual di Gunung Padang Desa Rawabogo Ciwidey. Melihat potensi yang dimiliki oleh Desa Rawabogo Ciwidey menjadi destinasi desa wisata.

Desa Wisata merupakan suatu kawasan pedesaan yang menawarkan suasana yang mencerminkan keaslian pedesaan. Mulai dari kehidupan sosial ekonomi, sosial budaya, adat istiadat, keseharian, memiliki arsitektur bangunan dan struktur tata ruang desa yang khas. Desa Rawabogo dikenal juga sebagai desa kreatif, beberapa kreativitas yang sudah diproduksi sebagai cinderamata adalah handycraf dari pelepah pisang yang dibuat lukisan. Lukisan dengan pasir laut, alat musik Karinding, seni budaya pertanian dan peternakan. Oleh-oleh berupa makan seperti dodol terong, keripik nanas, dan keripik peuyeum. Desa Rawabogo telah memiliki keunikan dan daya tarik kegiatan perekonomian dan mempunyai potensi untuk dikembangkannya menjadi desa wisata. Untuk memenuhi kebutuhan wisatawan di destinasi ada komponen-komponen Kepariwisataan harus dimiliki yaitu minimal 3A aksesibilitas, atraksi, akomodasi. Penelitian Utomo, dkk., (2017), terdapat dua konsep yang utama dalam komponen desa wisata, yaitu pertama, akomodasi adalah sebagian dari tempat tinggal para penduduk setempat dan atau unit-unit yang berkembang atas konsep tempat tinggal penduduk. Kedua, Atraksi adalah seluruh kehidupan keseharian penduduk setempat beserta setting fisik lokasi desa yang memungkinkan berintegrasinya wisatawan sebagai partisipasi aktif. 


\section{KESIMPULAN DAN REKOMENDASI}

Dari hasil penelitian dan pembahasan bahwa setiap desa yang ada di Indonesia memiliki potensi dasar yaitu kekayaan alam, keunikan budaya dan kuliner tradisional. Potensi dasar tersebut dapat di dikembangkan menjadi desa wisata sebagai diversifikasi produk wisata, memberikan kontribusi pada pembangunan desa dalam mengurangi tingkat penganguran dan meningkatkan kesejahteraan masyarakat. Secara adil dan merata serta peningkatkan kunjungan wisatawan ke Indonesia khususnya ke desa. Destinasi desa wisata kini menjadi trend dan di minati oleh wisman dan wisnu ikut terlibat dalam kehidupan masyarakat desa sehari-hari (live in), untuk memahami dan menghayati kehidupan pedesaan, yang gotong royong, aman, tentram dan damai jauh dari hiruk-pikuk dan kesibukan kota. Suasana alam pedesaan diharapkan tetap dapat dijaga dan dipertahankan keasriannya, tampa adanya pembangunan gedung-gedung baru yang akan merusak tatanan kehidupan desa dan mengurangi suasana alami pedesaan. Biarkan wisatawan tinggal dan berbaur bersama masyarakat di pedesaan.

\section{DAFTAR PUSTAKA}

a'inun, Fildzah., Krisnani, Hetty., Darwis, Rudi Sprudin. Padjadjaran, U. (2015). Pengembangan Desa Wisata Melalui Konsep Community Based Tourism (Pp. 341-346).

Bandung.

Https://Doi.Org/10.24198/Jppm.V2i3.13581

Bachri, Bactiar. (2010). Meyakinkan Validitas Data Melalui Triangulasi Pada Penelitian Kualitatif. Universitas Negri Surabaya. Surabaya.

Boeije, Hennie. (2010) Analysis In Qualitative Research. Sage Publications Ltd.

Hariyanto, O. I. . . (2017). The Meaning Of Offering Local Wisdom In Ritual Panjang Jimat. International Journal Of Scientific \& Technology Research, 6(06), 239-244. Retrieved From Http://Www.Ijstr.Org/FinalPrint/June2017/The-Meaning-Of-OfferingLocal-Wisdom-In-Ritual-Panjang-Jimat.Pdf

Koentjaraningrat. (2007) Sejarah Antropologi I Jakarta: UI Press

Khoiri, M. (2009). Makna Simbol Dan Pergeseran
Nilai Tradisi Upacara Adat Rebo Pungkasan. Universitas Islam Negeri Sunan Kalijaga, Yogyakarta. Retrieved From Http://Digilib.Uin-Suka.Ac.Id/3907/1/BAB I\%2CV\%2C Daftar Pustaka.Pdf

Munir, S. (2013). Diksi Dan Majas Dalam Kumpulan Puisi Nyanyian Dalam Kelam Karya Sutikno W.S: Kajian Stilistika. Universitas Negeri Semarang. Retrieved from

https://lib.unnes.ac.id/18013/1/2150408024. pdf

Nur Indah Ariyani, Argyo Demartoto, A. Z. (2015). Habitus Pengembangan Desa Wisata Kuwu: Studi Kasus Desa Wisata Kuwu Kecamatan Kradenan Kabupaten Grobogan. Jurnal Analisa Sosiolog, 4(2), 60-74. Retrieved from https://media.neliti.com/media/publications/ 227591-habitus-pengembangan-desawisata-kuwu-st-15801e56.pdf

Ratna, Nyoman Kutha. (2010). Metodologi Penelitian Kajian Buadaya dan Ilmu SosialHumaniora pada Umumnya. Pustaka Pelajar: Yogyakarta.

Sudjana., Hartati, S. (2011). Nukilan Kearifan Lokal Suku Sunda Berupa Anjuran Dan larangan. In (Psikologi, Ekonomi, Sastra, Arsitektur \& Sip (Vol. 4, pp. 14-17). Retrieved from http://repository.gunadarma.ac.id/384/

Utomo, Selamet Joko., Satriawan, B. (2017). Strategi Pengembangan Desa Wisata Di Kecamatan Karangploso Kabupaten Malan, 11(2), 142-153. Retrieved from https://www.researchgate.net/publication/32 2250381_Strategi_Pengembangan_Desa_W isata_Di_Kecamatan_Karangploso_Kabupa ten_Malang

\section{BIODATA PENULIS}

${ }^{1}$ Oda I. B. Haryanto dosen Progam Studi Pariwisata Universitas Internasional Batam mendapat gelar Doktor Ilmu Budaya dari Universitas Padjadjaran. Saat ini memiliki ketertarikan penelitian pada bidang Budaya, Pariwisata, dan Makanan .

${ }^{2}$ Dame Afrina Sihombing dosen Program Studi Mamajemen Universitas Internasional Batam, mendapat gelar Magister Manajemen dari 
Tradisi Ritual Masyarakat Desa Rawabogo Ciwidey... Oda I.B. Hariyanto et al.

Universitas Internasional Batam. Saat ini memiliki

ketertarikan penelitian pada bidang Manajemen dan Pariwisata. 